\title{
DESKRIPSI MODEL PENYELESAIAN KONFLIK AGAMA BUDDHA (STUDI TENTANG PENYELESAIAN KONFLIK UMAT THERAVADA DAN BUDDHAYANA DI DUSUN LENEK DESA BENTEK KECAMATAN GANGGA KABUPATEN LOMBOK UTARA)
}

\author{
Ayuniwati ${ }^{1}$ \\ Tri Yatno, S.Pd.B.,M.Si. ${ }^{2}$ \\ Prihadi Dwi Hatmono, S.Pd.B., M.Pd. ${ }^{3}$
}

\begin{abstract}
ABSTRAK
Kasus konflik intern agama Buddha yang terjadi di Dusun Lenek Desa Bentek Kecamatan Gangga Kabupaten Lombok Utara. Konflik yang terjadi seperti gesekan umat Theravada dengan umat Buddhayana. Konflik tersebut adalah bukti bahwa dalam internal agama Buddha terjadi gesekan. Tujuan dari penelitian ini adalah untuk mendeskripsikan pola penyelesaian konflik antar umat Theravada dengan umat Buddhayana dan menerapkan pola penyelesaian konflik antar umat Theravada dengan Buddhayana di Dusun Lenek. Jenis penelitian menggunakan penelitian kualitatif dengan pendekatan etnografi. Teknik analisis data menggunakan reduksi data, display data, dan kesimpulan. Subjek dalam penelitian ini adalah tokoh agama, tokoh masyarakat dan umat Buddha di Dusun Lenek. Objek dalam penelitian adalah kasus konflik yang terjadi antara umat Theravada dan Buddhayana di Dusun Lenek. Hasil penelitian menunjukan bahwa pola penyelesaian konflik yang diterapkan oleh umat Theravada dan Buddhayana adalah (a) sikap toleransi, mengembangkan sikap toleransi disini adalah adanya sikap saling menghargai dan menghormati. (b) Adanya sikap yang mau berdamai, dengan tidak mengembangkan sikap kemarahan dan kebencian. (c) mengembangkan sikap yang mau bekerjasma dalam hal apapun untuk mengembangkan agama Buddha ataupun mengembangkan Dusun Lenek.

Kata kunci: Umat Buddhayana, Umat Theravada, Konflik.
\end{abstract}

\begin{abstract}
Buddhis internal conflicts occurred at Lenek Bentek Gangga North Lombok. Reterey conflicts happens because of between friction here the Theravada and Buddhayana members. The conflict proves that there is Buddhism friction in internal Buddhis commuity. The of this study is to describe the patterns of conflict resolution between Theravada Buddhist and Buddhayana community and implement the conflict resolution pattern in Lenek.The type of research is qualitative research with ethnographic approach. Data were analyzed using data reduction, data display, and conclusion. Subjects in this study were religious leaders, community leaders and the Buddhist in Lenek. The object of this research conflict between Buddhayana and Theravada members in Lenek.The results showed that the pattern of conflict resolution adopted by the Buddhayana and Theravada members are. a) tolerance, develop the attitude of tolerance where there is mutual appreciation and respect. $b$ ) The attitudes of peace, not develop the attitude of anger and hatred.. ) develop the attitude on cooperatton and worktogether to develop Buddhism in Lenek.
\end{abstract}

Keywords : Pattern Conflict resoulution, Etnography.

\footnotetext{
${ }^{1}$ Dharmadutta STABN Raden Wijaya, email: ayuniwati16@yahoo.co.id

${ }^{2}$ Dosen STABN Raden Wijaya, email: triyatno920@yahoo.com

${ }^{3}$ Dosen STABN Raden Wijaya, email: hatmonoprihadi@ gmail.com
} 


\section{PENDAHULUAN}

\section{Latar Belakang Masalah}

Indonesia adalah Negara Bhineka, masyarakatnya memiliki keanekaragaman sosial dan budaya. Masyarakat Indonesia terdiri dari bermacam-macam budaya, ras, suku bangsa, bahasa dan kepercayaan. Perebedaanperbedaan yang ada dalam masyarakat Indonesia tersebar di seluruh pulau yang dimiliki oleh Negara Republik Indonesia. Keanekaragaman dalam masyarakat tersebut akan mempengaruhi kehidupan seharihari, seperti pola pikir, cara berperilaku, cara berkomunikasi dan cara berbusana. Perbedaan agama atau kepercayaan juga akan mempengaruhi suatu masyarakat dalam menjalin hubungan intern masyarakat pemeluk agama, antar masyarakat pemeluk agama, dan antara masyarakat pemeluk agama dengan pemerintah.

Pluralitas agama merupakan salah satu kekayaan budaya bangsa Indonesia. Apabila Kemajemukan dipandang sebagai hal yang negatif maka akan menjadi potensi munculnya konflik baik intern agama maupun antar umat beragama. Namun apabila kemajemukan tersebut dihargai dan diterima dengan bijaksana oleh masyarakat, maka akan tercipta kehidupan yang harmonis dan suasana kebinekaan sesuai dengan amanat yang tersirat dalam dasar Negara yaitu Pancasila. Di sisis lain, kemajemukan beragama dapat menjadi salah satu sumber terjadinya konflik. Konflik yang timbul berasal dari perbedaan pendapat antar pemeluk, yang mengakibatkan pertikaian dan ketidaknyaman bangsa (Pramudya, 2005: 1).

Pada dasarnya konflik tidak bisa lepas dari kehidupan masyarakat, karena permasalahanpermasalahan yang terjadi di masyarakat adalah suatu fenomena yang tidak dapat dihilangkan dalam suatu interaksi sosial. Dalam kehidupan bermasyarakat, konflik merupakan hal yang wajar dan biasa, karena setiap individu 
maupun kelompok mempunyai kepentingan yang berbeda-beda. Kelompok-kelompok yang berkonflik sesungguhnya saling berkaitan erat dengan yang lain dan bersama-sama berada dalam struktur yang luas.

Konflik agama juga bisa terjadi dalam intern agama. Salah satu contoh kasus konflik intern agama Buddha adalah yang terjadi di Dusun Lenek Desa Bentek Kecamatan Gangga Kabupaten Lombok Utara. Konflik yang ada seperti gesekan antar sekte. Konflik tersebut adalah bukti bahwa dalam internal agama Buddha terjadi gesekan. Gesekan antar umat Theravada dengan Buddhayana.

Masyarakat di Dusun Lenek mayoritas beragama Buddha. Agama Buddha di Dusun Lenek terbagi menjadi dua kelompok yaitu kelompok Theravada dan sekte Buddhayana. Berdasarkan pengamatan bahwa adanya gesekan antara umat Theravada dengan Buddhayana. Konflik yang terjadi di Dusun Lenek muncul karena adanya perbedaan kepentingan antar umat Theravada dengan Buddhayana, dan bukan merupakan konflik yang mempertentangkan ajaran agama atau kitab suci agama Buddha.

Konflik yang terjadi di Dusun Lenek berawal pada tahun 2004. Pada tahun 2004 agama Buddha di Dusun Lenek tepecah menjadi dua Vihara dan menjadi dua kelompok yaitu kelompok Theravada dan Buddhayana. Tindakan profokasi dilakukan dengan rasa egoisme dari seorang oknum untuk mendapatkan sebuah kedudukan dari umat Buddha dan menjadi pemimpin di Vihara. Terpecah belahnya agama Buddha di Dusun Lenek membuat umat Buddha masing-masing kelompok masih memilki sifat fanatisme terhadap sekte atau alirannya yang beranggapan bahwa ajaran dari sektenya-lah yang paling benar dan sekte yang lain dianggap salah. Dengan keadaan seperti itu sikap toleransi antar umat Buddha Theravada dan Buddhayana di Dusun Lenek menjadi lemah, karena satu sama 
lain masih saling mengklaim dan rasa kekeluargaan antar umat Buddha pun menjadi berkurang. Konflik dalam intern agama Buddha di Dusun Lenek bukanlah konflik yang berujung pada kekerasan atau bentrokan melainkan konflik agama Buddha di Dusun Lenek yang terjadi antara umat Theravada dan Buddhayana adalah konflik yang terjadi dengan saling mengklaim satu sama lain.

Sementara itu sikap para pemimpin umat Buddha di Dusun Lenek menunjukan respon yang negatif, artinya para pemimpin tidak sepakat untuk saling memperbaiki hubungan bersama tetapi mempertahankan pendapat masing-masing. Masalah tersebut berakibat pada kehidupan sosial dan ekonomi dalam masyarakat, hubungan sosial menjadi tidak harmonis, toleransi antar umat Buddha menjadi berkurang. Secara tidak lengsung kehidupan dalam bidang ekonomi menjadi terganggu, sebagai contoh misalnya umat yang berbeda sekte tidak mau melakukan transaksi ekonomi dengan sekte lain. Konflik intern agama Buddha sebenarnya sudah terjadi sejak zaman Sang Buddha masih hidup sampai dengan saat ini. Dalam Upakilesa Sutta, Majjhima Nikaya 7:128, terdapat kejadian dimana para Bhikkhu di Kosambi yang saling berselisih paham tentang ajaran Buddha. Konflik yang terjadi pada zaman Buddha terus mengekar hingga kini, baik gesekan antar sekte maupun kelompok/organisasi (Bodhi, 2008: 2113).

Dengan mengamati hal tersebut di atas maka penulis melakukan penelitian dengan judul "Deskripsi Model Penyelesaian Konflik Agama Buddha (Studi Tentang Penyelesaian Konflik umat Theravada dan Buddhayana di Dusun Lenek Desa Bentek Kecamatan Gangga Kabupaten Lombok Utara)". Alasan penulis melakukan penelitian di Dusun Lenek adalah karena di Dusun Lenek pernah terjadinya konflik intern agama Buddha yaitu 
konflik antar umat Theravada dan Buddhayana.

\section{Identifikasi Masalah}

Berdasarkan latar belakang masalah dapat di identifikasikan masalah sebagai berikut:

1. Adanya egoisme dari seorang pemimpin untuk mendapatkan sebuah kedudukan.

2. Adanya sifat fanatisme dari umat Buddha terhadap ajaran dari masing-masing sekte terhadap ajaran agama.

3. Lemahnya sikap toleransi antar umat Theravada dan Buddhayan di Dusun Lenek.

4. Adanya perbedaan pendapat antar umat Tehravada dan Buddhayana di Dusun Lenek.

5. Belum adanya usaha dari masing-masing umat untuk menyelesaikan konflik antar umat Theravada dan Buddhayana di Dusun Lenek.

\section{Batasan Masalah}

Mengingat luasnya
permasalahan yang berkaitan
disintegrasi intern umat beragama
Buddha yang terjadi di Dusun

Lenek, maka penulis membatasi penelitian pada Lemahnya sikap toleransi umat Theravada dan Buddhayana di Dusun Lenek dan Belum adanya usaha dari masingmasing sekte untuk menyelesaikan konflik antar umat Buddha Theravada dan Buddhayana di Dusun Lenek.

\section{Rumusan Masalah}

Berdasarkan batasan masalah tersebut, maka penulis merumuskan masalah sebagai berikut : Bagaimanakah pola penyelesaian konflik yang telah diterapkan antar umat Theravada dan Buddhayana di Dusun Lenek?

\section{Tujuan Penelitian}

Adapun tujuan dari penelitian dilakukan dengan judul "Deskripsi Model Penyelesaian Konflik Agama Buddha (Studi Tentang Penyelesaian Konflik umat Theravada dan Buddhayana di Dusun Lenek Desa Bentek Kecamatan Gangga Kabupaten Lombok Utara)" ini adalah:

Untuk mendeskrpsikan pola penyelesaian konflik antar umat 
Theravada dan Buddhayana yang terjadi di Dusun Lenek.

\section{LANDASAN TEORI}

\section{Theravada}

$$
\text { Demi memenuhi }
$$

kehendak umat dan panggilan kewajiban, maka anggota Sangha dan tokoh umat diskusi tercetuslah ide untuk membentuk Sangha baru. Pembentukan Sangha baru perlu pertimbangan yang banyak, antara lain dibentuk bukan untuk menyaingi Sangha yang sudah ada, namun hanya untuk memenuhi kebutuhan umat dalam hal pembinaan. Dengan demikian terbentuklah Sangha baru yang dinamakan Sangha Theravada Indonesia (STI) oleh lima orang Bhikkhu. Pembentukan STI ini disambut baik oleh tokoh-tokoh umat Buddha.(http://www.samaggi-

phala.or.id/naskah-

dhamma/buddhisme-theravada-danmahayana/) Di unduh pada tanggal 16 februari 2016.

Terdapat pokok-pokok pikiran yang berbeda antara sekte Theravada dengan yang lainnya.
Salah satu yang jelas yaitu mengenai Bodhisattva. Ada yang mengatakan bahwa salah satu sekte yaitu sekte Mahayana adalah tingkat ke-Arahat-an yang menuju ke tingkat ke-Buddha-an, sedangkan Theravada untuk tingkat ke-Arahat-an saja. Mahayana telah menciptakan banyak Bodhisattva mistis, sedangkan Theravada menganggap Bodhisattva sebagai seorang yang mengabdikan seluruh hidupnya mencapai kesempurnaan dan akhirnya menjadi seorang Buddha yang mencapai penerangan Agung guna kesejahteraan dunia, serta kebahagiaan umat. (http://www.samaggi-phala.or.id/naskahdhamma/pokok-pokok-dasar-pemersatutheravada-dan-mahayana/) Di unduh pada tanggal 16 februari 2016.

$$
\text { Sejarah perkembangan }
$$
agama Buddha pada awalnya bukan hanya agama tapi tradisi atau yang disebut dengan pemujaan. Kepercayaan masyrakat di Dususn Lenek merupakan suatu tradisi yang pada awalnya memuja sebuah 
benda-benda diantaranya dalam satu tahun itu ada dua pemujaan yaitu muja balit sama muja taon. Agama Buddha masuk di Dusun Lenek sekitar tahun 1970-an. Pada saat itu datang Bhikkhu Ashin Jinarakhita dari Jakarta dan datang juga bersama Romo Martimom dan Romo Komang Gede yang dari Lombok. Mereka bertiga datang ke Dusun Lenek ini untuk memperkenalkan agama Buddha Agama Buddha kepada masyarakat yang ada disini. (Wawancara dengan Rommo Sudhamma, 19 April 2016 ).

\section{Buddhayana}

Majelis Buddhayana Indonesia (MBI) adalah sebuah organisasi pengabdian umat Buddha yang tertua di Indonesia. Buddhayana adalah pandangan dengan semangat mempersatukan semua sekte dalam Agama Buddha. Di bawah bimbingan Sangha Agung Indonesia dan pembinaan Majelis Buddhayana Indonesia Vihara-vihara Buddhayana berkembang di seluruh pelosok Tanah Air. Setiap
Vihara Buddhayana akan ditemukan ciri-ciri Theravada, Mahayana dan Tantrayana. Buddhayana di tengah-tengah agama Buddha yang terdiri dari banyak sekte diantaranya Hinayana (Theravada), Mahayana dan Tantrayana. Buddhayana tidak mencampur adukan segmensegmen Theravada, Mahayana dan Tantrayana, tetapi mempelajari masing-masing dari sekte tersebut. Ketiga sekte tersebut berpegang pada Dhamma ajaran Sang Buddha (Tim Penyusun, 2003: 46).

\section{Konflik}

\section{Pengertian Konflik}

Wirawan (2013: 1), menyatakan konflik merupakan salah satu esensi dari kehidupan bermasyarakat dan perkembangan manusia yang mempunyai karakteristik yang berbeda-beda. Konflik diartikan sebagai suatu proses sosial antara dua orang atau lebih yang berusaha menyingkirkan pihak lain dengan cara menghancurkan 
atau membuatnya tidak berdaya.

Dari pengertian konflik beberapa ahli tersebut terdapat beberapa hal mengenai koflik yaitu adanya ketidaksepakatan, adanya perbedaan kepentingan atau ide/gagasan atar suatu kelompok maupun intern kelompok tertentu yang berdampak pada ketidaknyamanan dan disintegrasi dalam kelompok tersebut.

\section{Tipe-tipe Situasi Konflik}

James A.F Stoner dan Charles Wankel (Muspawi, 2014: 46), menyatakan ada lima jenis konflik yaitu:

a. Konflik Intrapersonal

Konflik intrapersonal adalah konflik yang terjadi dengan diri sendiri. Konflik seperti ini terjadi bila pada waktu yang sama seseorang memilki dua keinginan yang tidak dapat dipenuhi sekaligus (Muspawi，2014: 41).

b. Konflik Interpersonal
Pearson 1983 (Sarwono \& Meinarno, 2014: 67), manusia adalah makhluk sosial. Artinya, sebagai makhluk sosial, kita tidak dapat menjalin hubungan sendiri, kita selalu menjalin hubungan dengan orang lain, mencoba untuk mengenali dan memahami kebutuhan satu sama lain, membentuk interaksi, serta berusaha mempertahankan interaksi tersebut.

c. Konflik antar individu dan kelompok

Individu adalah seseorang manusia yang tidak hanya memilki peranan khas dalam lingkungan sosial, melainkan juga mempunyai keperibadian serta pola tingkah laku spesifik dirinya (Soelaeman, 2011 : 114).

d. Konflik antar kelompok sosial

Muchtar (2014: 95), menyatakan kelompok sosial adalah sekumpulan individu-individu yang mengkelompok, menyatu 


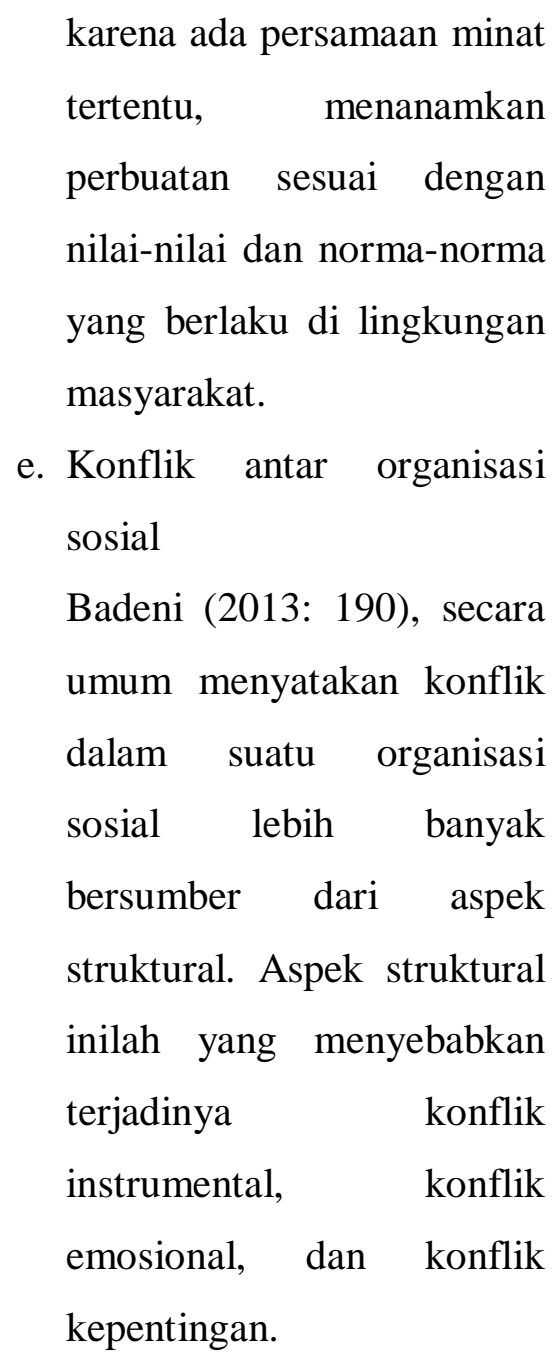

\section{Faktor-faktor}

Sebab Terjadinya Konflik

\author{
Secara umum faktor- \\ faktor yang menjadi akar \\ terjadinya konflik, antara lain \\ sebagai berikut (Ahmadi, 2009: \\ 291):
}
a. Perbedaan antar anggota masyarakat Masyarakat adalah sekelompok orang yang

memiliki perasaan sama atau menyatu satu sama lain yang saling berbagi identitas dan tinggal disuatu daerah tertentu dan mempunyai nilai-nilai dan norma-norma yang mengatur tata hidup masyarakat menuju tujuan yang sama (Suharto, 2014: 47).

b. Perbedaan pola kebudayaan Widagdho, dkk ( 2010: 21), menyatakan kebudayaan adalah keseluruhan sistem gagasan, tindakan dan hasil karya manusia untuk memenuhi kehidupannya dengan cara belajar, yang semuanya tersusun dalam kehidupan masyarakat. Kebudayaan itu diperoleh manusia sebagai anggota masyarakat. Tanpa masyarakat akan sukarlah bagi manusia untuk membentuk kebudayaan. Sebaliknya tanpa kebudayaan tidak mungkin manusia baik secara individual maupun 


$$
\begin{aligned}
& \text { masyarakat dapat } \\
& \text { mempertahankan } \\
& \text { kehidupannya. } \\
& \text { c. Perbedaan Status Sosial } \\
& \text { Status } \quad \text { (kedudukan), } \\
& \text { diartikan sebagai tempat } \\
& \text { atau pososi seseorang dalam } \\
& \text { suatu kelompok sosial. } \\
& \text { Kedudukan sosial artinya } \\
& \text { adalah tempat seseroang } \\
& \text { secara umum dalam } \\
& \text { masyarakatnya sehubungan } \\
& \text { dengan orang-orang lain, } \\
& \text { dalam arti lingkungan } \\
& \text { pergaulannya, dan hak-hak } \\
& \text { serta kewajiban- } \\
& \text { kewajibannya (Soekanto \& }
\end{aligned}
$$$$
\text { Sulistyowati , 2013: 210). }
$$$$
\text { d. Perbedaan Kepentingan }
$$

Badeni (2013: 188), konflik kepentingan merupakan konflik yang muncul antar anggota kelompok akibat adanya perbedaan kepentingan yang di dalamnya satu orang berusaha memaksimalkan kepentingan dan menghambat orang lain untuk mencapai tujuan atau kepentingannya. Setiap individu maupun kelompok mempunyai cara yang berbeda-beda dalam mengutamakan kepentingan. e. Terjadinya Perubahan Sosial Soekanto \& Sulistyowati (2013: 263), berpendapat bahwa perubahan sosial terjadi karena adanya perubahan dalam unsurunsur yang mempertahankan keseimbangan masyarakat. Kecenderungan terjadinya perubahan-perubahan sosial merupakan gejala wajar yang timbul dari pergaulan hidup manusia.

\section{Dampak Konflik}

Muchtar (2014: 100), menyatakan terdapat beberapa dampak konflik bagi kehidupan masyarakat yaitu mempunyai dampak negatif dan positif sebagai berikut:
a. Dampak Negatif
Adapun dampak negatif yang ditimbulkan oleh perselisihan dari segi teori antara lain sebagai berikut: 
1) Konflik

dapat

menimbulkan keretakan

hubungan antara individu

dan kelompok.

2) Konflik menyebabkan

rusaknya berbagai harta

benda dan jatuhnya

korban jiwa jika konflik

disertai

dengan

kekerasan.

3) Konflik menyebabkan

adanya

perubahan

keperibadian pada setiap individu.

4) Konflik menyebabkan dominasi kelompok

pemenang.

b. Dampak Positif

Adapun dampak positif yang ditimbulkan oleh perselisihan dari segi teori antara lain sebagai berikut:

1) Konflik dapat memperjelas berbagai aspek kehidupan yang masih belum tuntas

2) Adanya konflik

menimbulkan

menyesuaikan kembali norma-norma dan nilai- nilai yang berlaku dalam masyarakat.

3) Konflik dapat meningkatkan solidaritas diantara anggota

kelompok.

\section{A. Pola Penyelesaian Konflik}

Ada beberapa bentuk dan tingkat penyelesaian konflik yang bisa dilakukan yakni (Muchtar, 2014: 93):

a. Peace making (menciptakan perdamaian) yang biasa muncul dalam intervensi militer. Dinamika konflik biasanya berada pada peningkatan yang ditandai oleh reproduksi aksi kekerasan, mobilisasi masa dan tidak adanya komitmen mengentikan konflik.

b. Peace keeping (menjaga perdamaian) yang juga muncul dalam bentuk intervensi militer agar pihak ang sudak tidak bertikai tidak kembali telibat dalam konflik.

c. Conflict management (pengelolaan konflik), pada tahap ini mulai menciptakan 
berbagai usaha untuk

pemecahan masalah dengan

melibatkan berbagai pihak

dalam mencari pemecahan

masalah konflik.

d. Peace Building (pembangunan perdamaian), yang merupakan proses peningkatan kesejahteraan seluruh pihak yang bertikai.

\section{Integrasi Sosial}

\section{Pengertian Integrasi Sosial}

Integrasi sosial merupakan proses pembaharuan atau penyatuan antara dua kelompok, sehingga menjadi kesatuan yang utuh. Menurut Duverger (1881), integrasi adalah dibangunnya interdepensi yang lebih rapat antara bagian-bagian dari organisasi atau antara anggotaanggota di dalam masyarakat (Ahmadi, 2009: 297).

Dari pendapat ahli tersebut dapat disimpulkan bahwa integrasi adalah proses penyesuaian unsur-unsur yang berbeda dalam kehidupan bermasyarakat sehingga menghasilkan pola kehidupan masyarakat yang memiliki keserasian fungsi. Penyatuan antara dua kelompok yang berbeda dalam masyarakat, sehingga menjadi satu kesatuan yang utuh.

\section{Bentuk-bentuk Integrasi}

\section{Sosial}

Ahmadi (2009: 300), menjelaskan bentuk-bentuk integrasi antara lain integrasi keluarga, integrasi kekerabatan, integrasi asosiasi, integrasi masyarakat, asimilasi dan akulturasi.

a. Integrasi Keluarga

Keluarga adalah kelompok sosial kecil yang terdiri dari suami, istri, beserta anakanak. Keluarga biasa disebut dengan rumah tangga yang merupakan unit terkecil dalam masyarakat sebagai wadah atau proses pergaulan hidup. Fungsi dasar keluarga adalah memberikan rasa saling memiliki, rasa aman, kasih sayang dan 
mengembangkan hubungan

yang baik diantara keluarga.

b. Integrasi Kekerabatan

Integrasi kekerabatan

ditandai dengan tingkat kepatuhan integrasi antar anggota kekerabatan akan norma-norma dan nilai-nilai yang berlaku di dalam sistem kekerabatan tersebut. Integrasi kekerabatan sama halnya dalam keluarga, kekerabatan yang terbentuk melalui nilai-nilai, normanorma, kedudukan serta peranan sosial yang diakui dan ditaati bersama oleh seluruh anggota kekerabatan.

c. Integrasi Asosiasi

(Perkumpulan)

Asosiasi merupakan orang lain tertarik pada diri seseorang , karena terjadi asosiasi antara karakteristik yang seseorang miliki dengan hal-hal yang disukai orang tersebut. Di dalam benak seseorang sebenarnya ada skema tentang apapun, termasuk tentang karakteristik orang yang menarik dan tidak menarik (Rahman, 2013: 165).

d. Integrasi Masyarakat

Soelaeman (2011: 126), menyatakan bahwa masyarakat merupakan satuan lingkungan sosial yang bersifat makro. Aspek teritorium kurang ditekankan, namun aspek keteraturan sosial dan wawasan hidup kolektif memperoleh bobot yang lebih besar. Kedua aspek tersebut menunjuk kepada derajat integrasi masyarakat karena keteraturan esensial dan hidup kolektif ditentukan oleh kemantapan unsur-unsur masyarakat yang terdiri dari status dan peranan individu.

e. Asimilasi

Asimilasi adalah proses sosial yang ditandai dengan adanya usaha-usaha mengurangi perbedaanperbedaan yang terdapat diantara orang-perorangan atau kelompok-kelompok 
manusia dan juga meliputi usaha-usaha untuk mempertinggi kesatuan tindak, sikap dan prosesproses mental dengan memperhatikan kepentingan-kepentingan dan tujuan bersama (Pratiwi, 2009: 2).

f. Akulturasi Akulturasi adalah proses sosial yang timbul bila suatu kelompok manusia dengan suatu kebudayaan tertentu dihadapkan dengan unsurunsur dari suatu kelompok kebudayaan asing, sehingga unsur-unsur kebudayaan asing itu lambat laun diterima dan diolah ke dalam kebudayaan sendiri tanpa menyebabkan hilangnya keperibadian kebudayaan itu sendiri (Pratiwi, 2009: 3).

3. Faktor-faktor yang Mempengaruhi Integrasi Sosial

Ahmadi (2009: 298), menyatakan suatu integrasi dapat berlangsung cepat atau lambat tergantung faktor-faktor berikut:

a. Homogenitas kelompok

Sarwono \& Meinarno (2014: 167), menyatakan bahwa dalam kehidupannya individu tidak pernah lepas dari kelompok. Ketika individu lahir adalah bagian kecil dari kelompok kecil yang dinamakan keluarga. Selanjutnya individu mulai menjadi anggota dari berbagai kelompok di lingkungan masyarakat. Kelompok adalah dua orang atau lebih yang berinteraksi secara langsung, masingmasing peduli dengan hubungannya dalam sebuah kelompok, masing-masing peduli dengan orang lain yang menjadi anggota grup dan masing-masing peduli dengan ketergantungan positif mereka sehingga dapat berusaha mencapai tujuan bersama.

b. Besar kecilnya kelompok 
Umumnya dalam kelompok yang kecil tingkat kemajemukan anggota relatif rendah, sehingga integrasi sosial akan mudah dicapai. Hal ini bisa terjadi karena dalam kelompok kecil hubungan sosial antar anggota terjadi secara intensif, sehingga komunikasi dan tukar menukar budaya akan semakin cepat terjadi.

c. Mobilitas geografis Anggota kelompok atau masyarakat yang baru datang tentu harus menyesuaikan diri dengan identitas masyarakat yang dituju. Mobilitas sosiografis yang memungkinkan pertemuan antara masyarakat yang satu ke daerah yang lainnya sehingga terjadilah pembauran antar masyarakat.

d. Efektivitas komunikasi yang baik

Rogers \& D. Lawrence Kincaid 1982 (Cangara
2012: 22), menyatakan bahwa komunikasi adalah suatu proses dimana dua orang atau lebih melakukan pertukaran ide/gagasan atau informasi dengan satu sama lainnya, yang pada gilirannya akan tiba pada saling pengertian yang mendalam.

\section{Proses Terjadinya Integrasi Sosial}

Menurut Rosyid (2014: 24), menyatakan bahwa suatu proses integrasi sosial dapat tercipta apabila terpenuhi tiga persyaratan utama yaitu:

1. Adanya kesepakatan dari sebagian besar anggota terhadap nilai-nilai sosial tertentu yang bersifat fundamental dan krusial.

2. Sebagian terhimpun dalam berbagai unit sosial, saling mengawasi dalam aspekaspek sosial yang potensial.

3. Terjadi saling ketergantungan di antara kelompok-kelompok sosial yang terhimpun di dalam 
suatu masyarakat untuk pemenuhan kebutuhan ekonomi sosial secara menyeluruh.

\section{Syarat-syarat Terjadinya} Integrasi Sosial

Karsadi 1998
(Retnowati 2014: 193),
menggambarkan beberapa
syarat bagi masyarakat
heterogen untuk dapat
mencapai integrasi sosial
yaitu:

a. Anggota masyarakat merasa tidak dirugikan bahkan keuntungan diperoleh lebih besar.

b. Adanya penyesuaian paham tentang norma. Artinya tantangan dan bagaimana harus bertingkah laku untuk mencapai tujuan masyarakat.

c. Norma yang berlaku harus konsisten, untuk membentuk suatu struktur yang jelas.

\section{Toleransi}

\begin{tabular}{rrr}
\multicolumn{2}{c}{ Toleransi } & adalah \\
kesedian & untuk & menerima \\
kehadiran & orang lain yang
\end{tabular}

mempunyai agama atau keyakinan yang berbeda maupun orang yang mempunyai sekte yang berbeda khususnya di dalam agama Buddha. Toleransi ini merupakan konsekuensi dari pengakuan atas hak dan kebebasan yang sama dari setiap orang untuk hidup menurut keyakinan masingmasing (Mukti, 2003: 150).

\section{METODE PENELITIAN}

\section{Jenis Penelitian}

Jenis penelitian menggunakan penilitan kualitatif dengan pendekatan etnografi. Maulana (Herdiansyah, 2014: 75), menyatakan etnografi bahwa etnografi mencari insight sampai ke akarnya, mencari tahu " why people do what they do ", tidak hanya bersumber dari perkataan responden, melainkan diperkaya pula dengan hasil pengamatan, baik dalam bentuk aktivitas maupun foto, gambar dan simbol yang berhubungan dengan responden. 


\section{Tempat dan Waktu Penelitian}

Pada penelitian ini peneliti menentukan tempat penelitian di Dusun Lenek Desa Bentek Kecamatan Gangga Kabupaten Lombok Utara, yaitu di Vihara Sutta Dhamma dan Vihara Buddhavamsa. Adapun alasan peneliti memilih penelitian di Dusun Lenek adalah karena di Dusun Lenek terdapat konflik intern umat Buddha yaitu konflik antar umat Buddha Theravada dan Buddhayana. Waktu penelitian dari bulan Maret s.d Mei 2016.

\section{Subjek dan Objek Penelitian}

Subjek penelitian menurut Moleong adalah informan. Informan adalah orang yang dimanfaatkan untuk memberikan informasi tentang situasi dan kondisi tempat penelitian (Prastowo 2014: 195). Dalam penelitian ini yang bertidak sebagai subjek penelitian adalah tokoh agama Buddha, umat Buddha dan tokoh masyarakat yang ada di Dusun Lenek Desa Bentek Kecamatan Gangga Kabupaten Lombok Utara yang mengetahui dari awal terjadinya konflik antara umat Theravada dan Buddhayana.

Objek penelitian adalah tentang apa yang diselidiki dalam kegiatan penelitian (Prastowo, 2014: 199). Objek dalam penelitian ini adalah kasus konflik yang terjadi antara umat Theravada dan Buddhayana di Dusun Lenek Desa Bentek Kecamatan Gangga Kabupaten Lombok Utara.

\section{Teknik dan Instrumen \\ Pengumpulan Data}

\section{Teknik Pengumpulan Data}

a. Wawancara

Teknik wawancara yang dilakukan oleh peneliti untuk mengumpulkan data mengenai penyelesaian konflik yang terjadi di Dusun Lenek yaitu dengan wawancara etnografis. Wawancara etnografis yang dilakukan oleh peneliti yaitu dengan menggunakan bahasa sasak, bahasa yang biasa digunakan sehari-hari 
oleh masyarakat yang ada di

Dusun Lenek.

Wawancara
dilakukan bertujuan untuk
memperoleh informasi dan
menemukan apa yang orang
lain pikirkan dan rasakan
mengenai peristiwa konflik
yang terjadi di Dusun Lenek
dan upaya umat Buddha
dalam menyelesaikan
konflik yang terjadi antara
umat Theravada dan
Buddhayana. Informan yang
akan diwawancarai dalam
penelitian ini adalah tokoh
agama, tokoh masyarakat
dan umat Buddha dari
masing-masing kelompok
yang terlibat konflik.
Observasi

Observasi dilakukan untuk mendapatkan data dan fakta sebelum peneliti melakukan atau memasuki lapangan penelitian. Data yang diperoleh dalam observasi antara lain jumlah penduduk dusun Lenek berdasarkan pemeluk agama, umat Buddhis dari
Vihara Buddhavamsa dan Sutta Dhamma di Dusun Lenek yang terdiri dari anak-anak Sekolah Minggu Buddha, Remaja Buddhis dan Wanita Buddhis Indonesia, anggota Wandani, anggota Banjar Murmas 1 dan anggota Banjar Bina Warga, serta kegiatan-kegitan yang dilaksanakan oleh masingmasing Vihara. Mengati fakta yang terjadi di lapangan yaitu mengenai kondisi sosial masyarakat di Dusun Lenek, Interaksi sosial antara umat Theravada dan umat Buddhayana.

c. Dokumentasi

Studi dokumentasi yang dilakukan oleh peneliti bertujuan untuk memeperoleh informasi mengenai kondisi sosial lingkungan masyarakat di Dusun Lenek. Studi dokumentasi dilakukan dengan cara mengambil 
gambar maupun data primer lainnya.

\section{Instrumen Pengumpulan Data}

Dalam penelitian Kualitatif yang menjadi instrumen penelitian adalah peneliti itu sendiri. Peneliti kualitatif sebagai human instrument, berfungsi menetapkan informan sebagai sumber data, menetapkan fokus penelitian melakukan pengumpulan data, menilai kualitas data, analisis data, menafsirkan data dan membuat kesimpulan atas temuannya (Sugiyono, 2013: 59).

\section{Keabsahan Data}

Hasil-hasil analisis data yang dilakukan peneliti akan lebih akurat apabila dilakukan uji keabsahan melalui uji silang dengan informan lain, termasuk dengan informan penelitian. Teknik triangulasi lebih mengutamakan efektivitas proses dan hasil yang diinginkan. Triangulasi dapat dilakukan dengan menguji apakah proses hasil dan metode yang digunakan sudah berjalan dengan baik. Untuk memeperkuat dan membuktukan kebenaran data yang peroleh peneliti melalui wawancara, dokumentasi dan ovservasi maka peneliti menggunakan teknik Triangulasi.

(1) Peneliti menggunakan wawancara dan observasi partisipasi untuk pengumpulan data. Pastikan catatan harian wawancara dengan informan serta catatan harian observasi telah terhimpun. (2) Setelah itu dilakukan uji silang terhadap materi catatan-catatan harian untuk memastikan tidak ada informasi yang bertentangan antara catatan harian wawancara dan catatan harian observasi. Apabila antara catatan harian kedua metode ada yang tidak relevan, peneliti harus mengkonfirmasi perbedaan itu 
kepada informan. (3) Hasil konfirmasi perlu di uji kembali dengan informasi-informasi sebelumnya, karena bisa terjadi hasil konfirmasi itu bertentangan dengan informasi-informasi yang telah dihimpun sebelumnya dari informan atau sumber-sumber lain (Bungin, 2012: 203).

Apabila ada yang berbeda, peneliti terus menelusuri perbedaan-perbedaan itu sampai peneliti menemukan sumber perbedaan dan materi perbedaannya, kemudian dilakukan konfirmasi dengan informan serta sumber-sumber lain. Proses triangulasi dilakukan terus-menerus sepanjang proses mengumpulkan data dan analisis data, sampai suatu saat peneliti yakin bahwa sudah tidak ada lagi perbedaan-perbedaan dan tidak ada lagi yang perlu dikonfirmasikan kepada informan.

Teknik Analisis Data

1. Reduksi Data
Mereduksi

data

merupakan kegiatan merangkum, memilih hal-hal yang pokok, memfokuskan pada hal-hal penting. Catatancatatan lapangan dengan memilih hal-hal pokok yang berhubungan dengan konflik. Rangkuman catatan-catatan lapangan itu kemudian disusun secara sistematis agar memberikan gambaran yang lebih tajam serta mempermudah menemukan kembali apabila sewaktu-waktu data diperlukan kembali.

2. Display Data

$$
\text { Setelah data direduksi, }
$$
maka langkah selanjutnya adalah mendisplay data, berguna untuk melihat gambaran secara keseluruhan hasil penelitian. Kemudian dari hasil reduksi data dan display data itulah selanjutnya peneliti dapat menarik kesimpulan dan memverifikasi sehingga menjadi kebermaknaan data. 
Dalam penelitian ini akan diungkap mengenai makna dari data yang dikumpulkan. Verifikasi dilakukan dengan melihat kembali reduksi data maupun display data sehingga kesimpulan yang diambil tidak menyimpang dari data-data yang telah diperoleh. Verifikasi dilakukan sepanjang penelitian berlangsung dengan triangulasi sehingga menjamin signifikasi atau kebemaknaan hasil penelitian. Setelah verifikasi selsai maka dilakukan pembahasan hasil temuan di lapangan.

\section{HASIL PENELITIAN DAN PEMBAHASAN}

\section{Gambaran Umum Lokasi}

\section{Penelitian}

\section{Masyarakat Buddhis di Dusun Lenek}

Masyarakat Buddhis yang tinggal di Dusun Lenek Desa Bentek Kecamatan Gangga Kabupaten Lombok Utara dan menganut agama Buddha, masyarakat Buddha yang menetap di Dusun Lenek tersebut hidup berdasarkan asal-usul leluhur atau dapat dikatakan adanya turun temurun. Di Dusun Lenek juga dilengkapi fasilitas pendidikan antara lain terdapat gedung Sekolah Dasar (SD) sebanyak 1 unit dan terdapat Dhammasekha 1 unit. Sebagian besar masyarakat Buddhis di Dusun Lenek bekerja sebagai buruh tani. Aktifitas keagamaan kelompok masyarakat Buddhis di Dusun Lenek dapat dilihat dari kehidupan sehari-hari. Berikut ini jumlah umat Buddha di Dusun Lenek di bandingkan dengan jumlah penganut agama yang lain pada tahun 2016 .

\section{a. Vihara Sutta Dhamma}

Vihara

Sutta Dhamma merupakan salah satu Vihara yang ada di Dusun Lenek Desa Bentek Kecamatan Gangga Kabupaten Lombok Utara. Vihara Sutta Dhamma di bangun pertama kali di 
Dusun Lenek pada tahun 1976 direnovasi kembali pada tahun 2004 diresmikan pada tanggal 6 Februari 2006 yang pada saat itu diresmikan oleh Wakil Bupati Lombok Barat Bapak Hj.Muhammad Izul Islam dan Bhikkhu Viryanadi Mahatera.

\section{b. Vihara Buddhavamsa}

Vihara

Buddhavamsa merupakan salah satu Vihara Theravada yang ada di Dusun Lenek. Vihara Buddhavamsa di dirikan pada akhir tahun 2004 setelah umat Theravada memisahkan diri dari Vihara Sutta dhamma. Vihara Buddhavamsa awalnya hanya sebuah pondok biasa yang mana tempat tersebut tempat melakukan kebaktian dan hari raya dalam agama Buddha yang dilakukan oleh umat Theravada. Vihara Buddhavamsa mulai di bangun sektar tahun 2006 dan resmikan pada tanggal 6 Maret 2016.

\section{Agama Buddha di Dusun Lenek}

\section{a. Buddhayana}

Buddhayana

merupakan sebuah gerakan agama Buddha yang menghargai semangat pluralisme, dan nonsektarian. Umat Buddhayana bernaung di bawah bimbingan Sangha Agung Indonesia. Buddhayana merupakan salah satu sekte yang berkembang di Dusun Lenek Desa Bentek Kecamatan Gangga Kabupaten Lombok Utara. Jumlah umat Buddha sekte Buddhayana di Dusun Lenek lebih banyak jika dibandingkan dengan umat Buddha Theravada yang ada di Dusun Lenek. Umat Buddhayana di Dusun Lenek melakukan kegiatan puja bakti dengan menggunakan tiga versi atau mahzab yaitu mahzab 
Theravada (paritta suci), Mahzab Mahayana (sutra/leamkeng) dan Mahzab Tantrayana (mantra).

\section{b. Theravada}

Theravada merupakan salah satu sekte yang ada dalam agama Buddha. Sekte Theravada merupakan salah satu sekte yang berkembang di Dusun Lenek. Umat sekte Theravada di Dusun Lenek lebih sedikit jika dibandingkan dengan umat sekte Buddhayana. Sekte Theravada mempunyai perbedaan dengan sekte Buddhayana seperti dalam kegiatan puja bakti sekte Theravada hanya membancakan Paritta Suci atau versi Theravada dengan membacakan bahasa Pāli.

\section{Konflik di Dusun Lenek}

Konflik agama tidak hanya terjadi antara dua agama, tetapi konflik agama juga dapat terjadi di dalam intern agama. Seperti halnya konflik intern agama Buddha yang terjadi di Dusun Lenek yaitu konflik umat Theravada dengan umat Buddhayana. Hal tersebut membuktikan bahwa dalam agama Buddha terdapat gesekan-gesekan antar sekte. Konflik umat Theravada dan umat Buddhayana yang terjadi di Dusun Lenek membuktikan bahwa di dalam intern agama Buddha terjadi gesekan.

\section{Faktor Penyebab Konflik}

Faktor penyebab konflik umat Theravada dengan Buddhayana karena adanya perbedaan pendapat. Selain perbedaan pendapat tersebut sifat egois yang ada dalam kelompok juga merupakan salah satu pemicu terjadinya konflik umat Theravada dan umat Buddhayana. Adanya sikap fanatisme dari masing-masing yang tidak mau saling mengunjungi membuat konflik umat Theravada dan umat Buddhayana di Dusun Lenek tidak dapat terselesaikan dengan cepat. Salah satu 
pemicu terjadinya konflik umat Theravada dam Buddhayana yaitu karena politik seperti dalam hal pemilu. Konflik dalam pemilu ini terjadi ketika adanya pemilihan kepala daerah seperti Bupati. Perbedaan pendapat pemilihan kepala daerah ini dijadikan alasan sebagai pemicu terjadinya konflik.

\section{Pola Penyelesaian Konflik}

Keharmonisan akan terwujud apabila semua elemen masyarakat Buddhis memahamai bahwa agama Buddha mengalami perkembangan, dimana dalam perkembangnannya terdapat banyak perbedaan baik dari segi teori maupun praktik namun memiliki tujuan yang sama. Apabila ajaran Buddha diterapkan pada tiap-tiap kelompok dalam agama Buddha, maka tidak akan ada perselisihan dan perbedaan pendapat yang harus dijadikan sebuah alasan untuk terjadinya perpecahan di dalam agama Buddha. Untuk dapat menyelesaikan suatu konflik sosial yang terjadi di masyarakat, tentunya harus diketahui penyebab terjadinya konflik.

Untuk membentuk suatu keharmonisan antara umat Theravada dengan umat Buddhyana yaitu dengan mengadakan Anjangsana atau saling mengunjungi satu sama lain. Berikut model pola penyelesaian konflik yang diterapkan oleh umat Theravada dan umat Buddhayana di Dusun Lenek; (a) mengembangkan sikap toleransi, sikap toleransi disini adalah adanya sikap saling menghargai dan menghormati sesama agama Buddha maupaun agama lain, menerima perbedaan antar 
setiap orang sebagai hal yang wajar. Menghormati sesama intern umat Buddha dan tidak saling mengkelaim satu sama lain. (b) Adanya sikap yang mau berdamai, dengan tidak mengembangkan sikap kemarahan dan kebencian khusunya sesama agama Buddha itu sendiri. (c) mengembangkan sikap yang mau bekerjasma dalam hal apapun untuk mengembangkan agama Buddha ataupun mengembangkan Dusun Lenek. Berdasarkan ke empat poin pola penyelesaian konflik yang telah di dijelaskan oleh Muchtar (2014: 93), terdapat dua poin yang mendeketi dengan pola penyelesaian konflik yang telah diterapkan oleh umat Theravada dengan umat Buddhayana di Dusun Lenek. Kedua poin penyelesaian konflik tersebut ialah conflict management (pengelolaan konflik) dan peace building (pembangunan perdamaian). Conflict management (pengelolaan konflik), pada tahap ini mulai menciptakan berbagai usaha untuk pemecahan masalah dengan melibatkan berbagai pihak dalam mencari pemecahan masalah konflik. Umat Buddha di Dusun Lenek telah menciptakan berbagai usaha seperti salah satunya dengan mengadakan duduk bersama antara tokoh agama, tokoh masyarakat, dan umat Buddha untuk menemukan solusi agar konflik umat Theravada dengan Buddhayana tidak berkelanjutan dan dapat terselesaiakan serta melaksanakan Anjangsana saling mengunjungi satu sama lain. Peace Building (pembangunan perdamaian), yang merupakan proses peningkatan kesejahteraan seluruh pihak yang bertikai. Dalam hal ini untuk menciptakan suatu kerukunan dan kesejahteraan masyarakat umat Buddha di Dusun Lenek maka telah diterapkan sebuah penyelesaian konflik dengan adanya sikap toleransi, sikap 
berdamai dengan tidak mengembangkan kebencian, bergontong royong atau bekerjasama dalam mengembngkan agama Buddha dan melestarikan ajaran Buddha.

\section{Kesimpulan}

Berdasarkan data yang telah diperoleh melalui beberapa informan peneliti menemukan model penyelesaian konflik yang telah diterapkan oleh umat Theravada dan umat Buddhayana sebagai berikut: mengembangkan sikap toleransi, sikap toleransi disini adalah adanya sikap saling menghargai dan menghormati sesama agama Buddha maupaun agama lain, menerima perbedaan antar setiap orang sebagai hal yang wajar. Menghormati sesama intern umat Buddha dan tidak saling mengkelaim satu sama lain. (b) Adanya sikap yang mau berdamai, dengan tidak mengembangkan sikap kemarahan dan kebencian khusunya sesama agama Buddha itu sendiri. (c) mengembangkan sikap yang mau bekerjasma dalam hal apapun untuk mengembangkan agama Buddha ataupun mengembangkan Dusun Lenek.

\section{Saran}

1. Kepada masyarakat atau umat Buddha di Dusun Lenek untuk terus membentuk hubungan yang rukun dan harmonis intern pemeluk agama Buddha maupun ekstern agama Buddha.

2. Kepada para tokoh agama, diharapkan untuk tetap mengupayakan dalam membantu menciptakan kondisi masyarakat yang rukun dan harmonis, dengan cara tidak menanamkan sikap fanatisme agama yang akan mengarah pada timbulnya konflik intern maupun ekstern agama Buddha.

3. Kepada tokoh masyarakat dan pemerintah daerah yang berada dalam pemerintahan Dusun Lenek Desa Bentek Kecamatan Gangga Kabupaten Lombok Utara diharapkan mampu memberikan keamanaan (menjaga) warganya untuk melakukan tindakan yang tidak melanggar norma-norma 
agama atau aturan pemerintah serta menanamkan sikap adil dalam bentuk apapun terhadap sesama pemeluk agama

\section{DAFTAR PUSTAKA}

Ahmadi, Abu. (2009). Psikologi Sosial. Jakarta: PT Rineka Cipta.

Badeni. (2013). Kepemimpinan dan Prilaku Organisasi. Bandung: Alfabeta.

Bodhi. (2008). Majjhima Nikaya 7 Kitab Suci Agama Buddha. Klaten: Wisma Sambodhi. http://www.samaggiphala.or.id/naskahdhamma/buddhisme-theravadadan-mahayana/. Di unduh pada tanggal 16 februari 2016.

Cangara, Hafied. (2012). Pengantar Ilmu Komunikasi. Jakarta: PT Rajagrafindo Persada.

Herdiansyah, Haris. (2010). Metodologi Penelitian Kualitatif Untuk Ilmu-Ilmu Sosial. Jakarta: Salemba Humanika.

Muchtar. I.H. (2014). Dinamika Hubungan Antar Umat Beragama: studi Kasus Penanganan Konflik Umat Buddha Tri Dharma dengan Konghucu (Makin) Kecamatan

Pemangkat Kabupaten Samabas Kalimantan Barat, Jurnal Multikultural \& Multireligius (Nomor 1). Hlm 93 \& 102-103.

Mukti. K.W. (2001). Buddhayana. Jakarta: Yayasan Dian Dharma.
Buddha, sehingga tercipta suatu hubungan yang rukun dan harmonis dalam kehidupan masyarakat setempat.

Muspawi, Mohamad. (2014). Manajemen Konflik (Upaya Penyelsaian Konflik Dalam Organisasi), Jurnal Penelitian Universitas Jambi Seri Humaniora (Nomor 2). $\quad$ Hlm 46.

Prastowo. A. (2014). Metode Penelitian Kualitatif dalam Perspektif Rancangan Penelitian. Jogjakarta: Ar. Ruzz Media.

Pratiwi. P.H. (2009). Asimilasi dan Akulturasi: Sebuah Tinjauan Konsep.http://staff.uny.ac.id/sites/ default/files/pengabdian/poerwant i-hadi-pratiwi- spdmsi/asimilasi-akulturasi.pdf. Pada tanggal 18 Februari 2016.

Rahman. A.A. (2013). Psikologi Sosial Integrasi Pengetahuan Wahyu dan Pengetahuan Empirik. Jakarta. PT Raja Grafindo Persada.

Retnowati. (2014). Agama, Konflik, dan Integrasi Sosial. Jurnal Pengkajian Masalah Sosial Keagamaan. (Nomor 2). HIm 193.

Rosyid. M. (2014). Agama dan Budaya dalam Integrasi Sosial (Belajar dari Masyarakat Fakfak di Provonsi Papua Barat), Jurnal Multikultural \& Multireligius (Nomor 1). HIm 24.

Sarwono. S.W \& Meinarno, E.A. (2014). Psikologi Sosial. Jakarta: Salemba Humanika. 
Soekanto. S \& Sulistyowati. B. (2013). Sosiologi Suatu Pengantar. Jakarta : PT Raja Grafindo Persada.

Soelaeman. M. M. (2011). Ilmu Sosial Dasar Teori dan Konsep Ilmu Sosial. Bandung: PT Refika Aditama.

Sugiyono. (2013). Memahami Penelitian Kualitatif. Bandung: Alfabeta.

Suharto, Edi. (2014). Membangun Masyarakat Memberdayakan
Rakyat. Bandung: PT Refika Aditama.

Tim Penyusun. (2003). Kapita Selekta Agama Buddha. Jakarta: CV. Dewi Kayama Abadi.

Widgadho. D. dkk. (2010). Ilmu Budaya Dasar. Jakarta: Bumi Aksara.

Wirawan. (2013). Konflik dan Manajemen Konflik Teori, Aplikasi, dan Penelitian.

Jakarta: Salemba Humanika 